\title{
Declaração de Singapura sobre Integridade em Pesquisa
}

Preâmbulo. O valor e os benefícios provenientes da pesquisa dependem essencialmente da sua integridade. Embora haja diferenças entre países e entre disciplinas na maneira pela qual a pesquisa é organizada e conduzida, há também princípios e responsabilidades profissionais comuns que são fundamentais para a integridade da mesma, onde quer que seja realizada.

\author{
PRINCÍPIOS \\ Honestidade em todos os aspectos da pesquisa. \\ Responsabilização na condução da pesquisa. \\ Respeito e imparcialidade profissionais no trabalho com outros. \\ Boa gestão da pesquisa em benefício de outros.
}

1. Integridade: Os pesquisadores devem assumir a responsabilidade pela confiabilidade de suas pesquisas

\section{Cumprimento com as regras: Os}

pesquisadores devem estar cientes das regras e políticas de pesquisa e segui-las em todas as etapas.

3. Métodos de pesquisa: Os pesquisadores devem utilizar métodos de pesquisa apropriados, embasar as conclusões em uma análise crítica das evidências e relatar os achados e interpretações de maneira integral e objetiva.

\section{Documentação da pesquisa: Os}

pesquisadores devem manter documentação clara e precisa de suas pesquisas, de maneira que sempre permita a averiguação e replicação do seu trabalho por outros.

5. Resultados: Os pesquisadores devem compartilhar seus dados e achados pronta e abertamente, após assegurarem a oportunidade de estabelecer a prioridade e propriedade sobre os mesmos.

6. Autoria: Os pesquisadores devem assumir plena responsabilidade pelas suas contribuições em todas as publicações, solicitações de financiamento, relatórios e outras representações de suas pesquisas. A lista de autores deve sempre incluir todos aqueles (mas apenas aqueles) que atendam os critérios de autoria.

\section{Agradecimentos na publicação: Nas} publicações, os pesquisadores devem reconhecer os nomes e papéis daqueles que fizeram contribuições significativas à pesquisa, inclusive redatores, financiadores,

patrocinadores e outros, mas que não atendem aos critérios de autoria.

8. Revisão de pares: Ao participar da avaliação do trabalho de outros, os pesquisadores devem fornecer pareceres imparciais, oportunos e rigorosos.

9. Conflitos de interesse: Os pesquisadores devem revelar quaisquer conflitos de interesse, sejam financeiros ou de outra natureza, que possam comprometer a confiabilidade de seu trabalho nos projetos, publicações e comunicações públicas de suas pesquisas, assim como, em todas as atividades de revisão.

10. Comunicação pública: Os pesquisadores devem limitar seus comentários profissionais à sua própria área de especialização reconhecida quando participarem em discussões públicas sobre a aplicação e relevância de resultados de pesquisa, e devem distinguir claramente entre comentários profissionais e opiniões baseadas em visões pessoais.

11. Notificação de práticas de pesquisa irresponsáveis: Os pesquisadores devem notificar às autoridades competentes qualquer suspeita de má conduta profissional, inclusive a fabricação e/ou falsificação de resultados, plágio e outras práticas de pesquisa irresponsáveis que comprometam a confiabilidade da pesquisa, tais como desleixo, inclusão inapropriada de autores, negligência no relato de dados conflitantes ou uso de métodos analíticos enganosos.

12. Resposta a alegações de práticas de pesquisa irresponsáveis: As instituições de pesquisa, assim como as revistas, organizações profissionais e agências que tiverem compromissos com a pesquisa em questão devem dispor de procedimentos para responder a alegações de má conduta e outras práticas de pesquisa irresponsáveis, assim como proteger aqueles que, de boa fé, tenham denunciado tais comportamentos. Quando for confirmada a má conduta ou outra prática de pesquisa irresponsável, devem ser tomadas as medidas cabíveis prontamente, inclusive a correção da documentação da pesquisa.

13. Ambientes de pesquisa: As instituições de pesquisa devem criar e sustentar ambientes que incentivem a integridade através da educação, políticas claras e normas razoáveis para o progresso da pesquisa, ao mesmo tempo em que fomentam ambientes de trabalho que apóiem a integridade da mesma.

14. Considerações sociais: Os pesquisadores e as instituições de pesquisa devem reconhecer que têm uma obrigação ética no sentido de pesar os benefícios sociais contra os riscos inerentes apresentados pelo seu trabalho. 